\title{
PENGARUH FREKUENSI PIJAT BAYI TERHADAP KUALITAS TIDUR BAYI USIA 1-3 BULAN DI MOMBYKIDS JOMBANG
}

\section{Effect Of Baby Massage Frequency On Baby Sleep Quality 1-3 Months In Mombykids Jombang}

\author{
Fera Yuli Setiyaningsih, S. St. M. Keb \\ Dosen D3 Kebidanan \\ Prodi D3 Kebidanan STIKes ICMe Jombang \\ Jl. Kemuning No.57A, Candi Mulyo, Jombang, Jawa Timur \\ 61419 Telp (0321854916) \\ fera.yuli@gmail.com
}

\begin{abstract}
Abstrak
Tidur nyenyak merupakan kebutuhan yang harus dipenuhi oleh bayi karena pada saat tidur tersebut perkembangan otak mencapai puncaknya. Namun pada penelitian diperoleh bahwa 51,3 \% bayi mengalami gangguan tidur, $42 \%$ bayi tidur malamnya kurang dari 9 jam, dan pada malam hari terbangun lebih dari 3 kali dengan lama bangun lebih dari satu jam. Penelitian ini bertujuan untuk mengetahui pengaruh pijat bayi terhadap kualitas tidur usia 1-3 bulan di mombykids. Metode penelitian : Desain penelitian yang digunakan Case Control penelitian dilakukan pada bulan November dengan jumlah sampel 30 bayi yang terbagi dalam dua kelompok yaitu kelompok kontrol terdiri dari 15 bayi, kelompok kasus terdiri dari 15 bayi. Teknik pengambilan sampel menggunakan total sampling. Analisa data menggunakan Chi Square. Hasil penelitian : hasil analisis Chi Square nilai $\mathrm{p}=0.027<0.05$ sehingga bisa disimpulkan bahwa terdapat pengaruh antara pijat bayi dengan kulitas tidur bayi usia 1-3 bulan.
\end{abstract}

Kata Kunci : Pijat, Bayi, Kualitas tidur, Hormon serotonin

\begin{abstract}
Sleep well is a need that must be solved by the baby because at this time sleep brain development reaches its peak. $51.3 \%$ of babies experience sleep disturbances, $42 \%$ of babies sleep less than 9 hours a night, and at night they wake up more than 3 times with an increase of more than one hour. This study discusses baby massage on sleep quality 1-3 months in mombykids. Research method: Design of the study used Case control study was conducted in November with a sample of 30 infants divided into two groups, namely the control group consisting of 15 infants, the report group consisted of 15 infants. The sampling technique uses total sampling. Data analysis using Chi Square. The results of the study: the results of Chi Square analysis $p=0.027<0.05$ so that it can be concluded related to infant massage with the quality of sleep for infants aged 1-3 months.
\end{abstract}

Keywords: Massage, Infants, Sleep Quality, Serotonin Hormones 


\section{PENDAHULUAN}

Tidur adalah siklus proses fisiologis yang bergantian dengan periode bangun yang lebih lama. Tidur adalah prioritas utama untuk bayi, karena saat ini ada perbaikan neuro-brain dan sekitar $75 \%$ hormon pertumbuhan yang dihasilkan. Bayi menghabiskan jumlah waktu tidur rata-rata sekitar $60 \%$. Kualitas tidur bayi tidak hanya mempengaruhi perkembangan fisik, tetapi juga sikap pada hari berikutnya. Bayi yang tidur nyenyak tanpa sering bangun akan bugar dan tidak mudah rewel. Gangguan tidur pada bayi adalah jika bayi tersebut tidur kurang dari 9 jam pada malam hari, bayi sering terbangun lebih dari 3 kali dan bayi bangun lebih dari 1 jam. Bayi pada saat tidur rewel, mengangis dan menunjukkan sulit untuk kambali tidur (Gress et al, 2010).

Aktivitas regenerasi sel-sel tubuh dan tumbuh kembang otak berlangsung mencapai puncaknya pada saat bayi dan balita sedang tidur. Oleh karena itu tidur merupakan salah satu aktivitas penting dalam proses perkembangan anak (Wong dan Indraningsih, 2011). Pola tidur bayi berbeda-beda. Namun kebutuhan tidur bayi yang baru lahir sangat banyak. Setiap 3 jam sekali, bayi akan terjaga untuk minum. Dengan bertambahnya usia, kebutuhan tidur semakin berkurang. Bayi akan tidur di malam hari, sedangkan di siang harinya bayi akan terjaga. Pada usia 6 bulan bayi akan tidur sejenak di pagi hari. Sedangkan disiang hari akan terjaga. Pada malam hari bayi tertidur pula dan akan terjaga menjelang subuh untuk menyusu (Widyastuti dan Widyani, 2006).

Hasil penelitian Sekartini (2004) menyatakan bahwa dari 285 bayi yang menjadi responden dalam penelitian tersebut terdapat $51,3 \%$ bayi mengalami masalah tidur, $42 \%$ bayi tidur malam kurang dari 9 jam dan pada malam hari bayi tersebut bangun lebih dari 3 kali dengan lama bangun lebih dari 1 jam.

Pada usia 1 tahun umumnya bayi akan tidur sepanjang malam kira-kira 10-12 jam dan tidur siang sekali saja. Tercukupinya kebutuhan tidur bagi bayi akan menunjang perkembangan kecerdasan emosional. Kecerdasan emosional bayi akan berpengaruh pada kepribadiannya. Kepribadian bayi akan tumbuh, jika bayi telah memiliki kemampuan untuk melakukan sesuatu yang baru. Misalnya, bayi akan merasa bangga saat ia memiliki kemampuan mengangkat kedua tanggnya untuk merangkat (Widyastuti dan Widayani, 2006). Bayi adalah individu yang lemah dan membutuhkan beberapa adaptasi, jadi jika bayi mengalami kesulitan dalam proses adaptasi, maka akan mempengaruhi perkembangannya, menyebabkan perilaku tidak teratur, bahkan konsekuensi yang paling fatal adalah kematian (Mansyur, 2009). Tidur pulas atau tidur yang nyenyak penting untuk pertumbuhan bayi, pada saat tidur otak akan berkembang mencapai puncaknya. Pada saat tidur tubuh bayi akan memproduksi hormon sebanyak 3 kali lipat jika dibandingan ketika bayi terbangun (Gola, 2009).

Waktu tidur sudah ditentukan dengan yang disebut " irama Sirkadian tubuh" yaitu suatu kebiasaan alami untuk mengularng proses biologi yang terjadi di dalam tubuh. Irama sirkadian bisa juga disebut dengan istilah jam biologis tubuh. Dengan adanya irama tubuh ini maka tubuh akan selalu mengantuk di malam hari, terjaga di pagi hari, sedikit mengantuk di siang menjelang sore hari. Kebutuhan tidur bayi usia 1-3 bulan kirakira 12-18 jam

Kualitas tidur bayi dipengaruhi oleh beberapa faktor. Kualitas tersebut dituntukkan dnegan kemampuan seseorang utuk bisa tidur dan mendapatkan jumlah waktu istirahat sesuai dengan kebutuhan. Pentingnya pemenuhan tidur untuk perkembangan bayi maka kebutuhan tidur pada bayi harus dipenuhi secara maksimal. Salah satu cara yang bisa dilakukan adalah dengan pemberian latihan fisik atau pijatan. Bayi yang mendapatkan pijatan bisa tidur dengan nyenyak (Roesli, 2001).

Berdasarkan studi pendahuluan yang di lakukan di Mombykids jombang diperoleh data bahwa ibu yang mempunyai bayi usia 1-3 bulan berjumlah 23 orang dan dari data tersebut ada sekitar 10 orang yang rutin untuk melakukan pijat bayi. Dari pendahuluan di atas maka peneliti tertarik untuk mengetahui pengaruh frekuensi pijat bayi dengan terhadap kualitas tidur bayi usia 1-3 bulan 


\section{METODE PENELITIAN}

Desain penelitian yang digunakan adalah Case Control, case control adalah penelitian analitik observasional yang banyak digunakan pada bidang epidemiologi (Swarjana, 2012). Populasi dalam penelitian adalah bayi usia 1-3 bulan di Mombykids pada bulan November 2018 yang berjumlah 30 bayi. Pada penelitian terdiri dari dua kelompok penelitian yaitu kelompok kontrol yang artinya adalah kelompok tanpa perlakuan, yang kedua adalah kelompok kasus atau kelompok dengan perlakuan. perlakuan berupa pijat bayi yang dilakukan selama satu bulan. Setiap kelompok terdiri dari 15 bayi. Sampel yang diambil oleh peneliti adalah 30 bayi teknik pengambilan sampling adalah total sampling. Pengumpulan data menggunakan kuesioner, sedangkan untuk analisisnya menggunakan uji Chi Square.

\section{HASIL PENELITIAN}

Karakteristik Bayi

Tabel 1 Karakteristik Responden

\begin{tabular}{lcccc}
\hline \multirow{2}{*}{ Karakteristik } & \multicolumn{2}{c}{ Kelompok Kontrol } & \multicolumn{2}{c}{ Kelompok Kasus } \\
& Frekuensi & Persentase (\%) & Frekuensi & Persentase (\%) \\
\hline Umur Bayi & & & & \\
a. 1 bulan & 3 & 20 & 5 & 33.3 \\
b. 2 bulan & 6 & 40 & 6 & 40 \\
c. 3 bulan & 6 & 40 & 4 & 26.7 \\
$\quad$ Total & 15 & 100 & 15 & 100 \\
\hline Jenis Kelamin & 4 & & & 33.3 \\
a. Laki-laki & 11 & 26.7 & 5 & 66.7 \\
b. Perempuan & 15 & 73 & 10 & 100 \\
$\quad$ Total & 100 & 15 & \\
\hline
\end{tabular}

Berdasarkan tabel di atas dapat diketahui bahwa distribusi bayi berdasarkan umur pada kelompok kontrol tertinggi pada bayi usia 2 dan 3 bulan yaitu sebayak 6 bayi (40\%). Distribusi terendah pada usia 1 bulan yaitu berjumlah 3 bayi (20\%). Pada kelompok kasus berdasarkan umur distribusi tertinggi pada bayi usia 2 bulan berjumlah 6 bayi
(40\%), distribusi terendah pada bayi usia 3 bulan yaitu 4 bayi $(26,7 \%)$.

Karakteristik bayi berdasarkan jenis kelamin pada kelompok kontrol distribusi tertinggi pada jenis kelamin perempuan yaitu 11 bayi (73\%). Pada kelompok kasus distribusi tertinggi bayi perempuan berjumlah 10 bayi $(66,7 \%)$.

\section{Pijat Bayi}

Tabel 2 Frekuensi Pijat Bayi Selama 1 Bulan

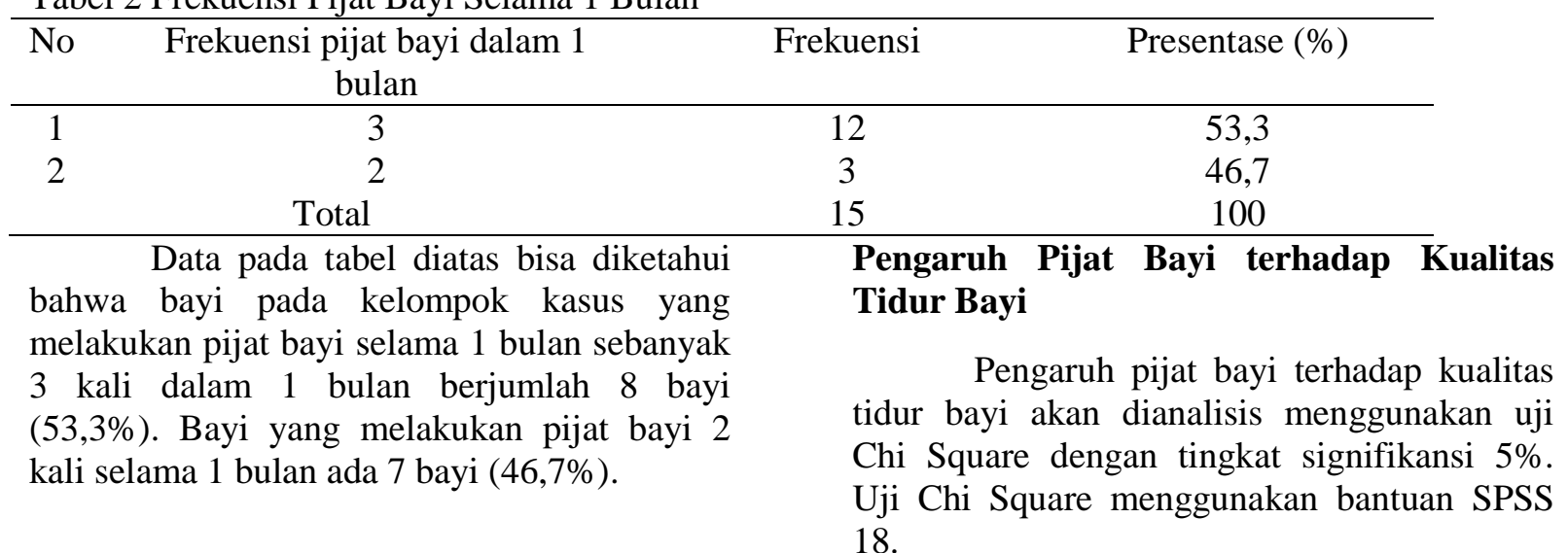
18. 
Tabel 3 Hasil Uji Chi Square Pengaruh Frekuensi Pijat Bayi terhadap Kualitas Tidur Bayi Usia 1-3 Bulan

\begin{tabular}{cccccccc}
\hline \multirow{2}{*}{ Pijat bayi } & \multicolumn{2}{c}{ Buruk } & \multicolumn{2}{c}{ Kualitas tidur bayi } & \multicolumn{2}{c}{ Total } \\
& Frek & $\%$ & Frek & $\%$ & Baik & $\%$ \\
\hline Control & 10 & 66,7 & 5 & 33.3 & 15 & 100 \\
& & & & & & 15 & 100 \\
Kasus & 3 & 40 & 12 & 60 & 30 & 100 \\
Total & 16 & 53.3 & 14 & 46.7 & 30 \\
\hline
\end{tabular}

Berdasarkan dari data tersebut diketahui bahwa pada kelompok kontrol bayi yang mempunyai kualitas tidur baik lebih rendah yaitu 5 bayi (33.3\%) dibandingkan dengan bayi yang mempunyai kualitas tidur yang buruk yaitu 10 bayi $(66.7 \%)$. Pada kelompok kasus atau kelompok dengan perlakuan berupa pijat bayi diperoleh hasil 9 bayi $(60 \%)$ memiliki kualitas tidur baik dan 6 bayi $(40 \%$ ) memiliki kualitas tidur yang buruk. Hasil analisis chi square (Lampiran 1) diperoleh bahwa pijat bayi memberikan pengaruh pada kulaitas tidur bayi dengan nilai signifikansi 0.027 .

\section{PEMBAHASAN}

Hasil penelitian pengaruh pijat terhadap kualitas tidur bayi dengan analisis chi square nilai $\mathrm{p}=0.027<0.05$ artinya bahwa pijat bayi mempengaruhi kualitas tidur bayi. Hasil ini menunjukkan bahwa bayi yang diberikan pijat bayi secara rutin memiliki kualitas tidur yang lebih baik dibandingkan bayi yang tidak melakukan pijat bayi sama sekali.

Penelitian Kusumastuti, et al., 2016 mengatakan bahwa pijat bayi dapat meningkatkan kualitas tidur bayi, tidak hanya kualitas tidur bayi saja namun meningkatkan perkembangan motorik kasar dan motorik halus pada bayi. Sofa, et al., 2013 mengatakan bahwa bayi yang memperoleh pijatan memiliki kualitas tidur yang dan tidur lebih tenang serta tidak rewel. Berdasarkan penelitia Haniyyah, et al. 2013 menyatakan bahwa pijat bayi sangat efektif dalam mengatasi gangguan tidur selain itu pijat bayi juga mempengaruhi proses tumbuh kembang bayi. Pijat bayi merupakan asuhan utama yang diberikan pada bayi dan bayi beresiko beresiko tinggi juga dilaporkan lebih sering menggunakan pijat bayi untuk membantu pemenuhan kebutuhan tidur yang baik, pernapasan, kencing bayi, mengurangi kolik dan stres, serta mempengaruhi interaksi antara ibu dengan bayi dengan cara positif (Underdown, et al, 2006).

Pijat bayi bisa meningkatkan hormon serotonin yang memproduksi melatonin, melatonin berperan dalam tidur serta membuat tidur lebih lama dan lelap pada malam hari. Serotonin juga bisa meningkatkan reseptor yang berperan dalam meningkatkan glukokortiroid dan adrenalin (hormon stres). Adanya proses tersebut membuat hormon stres menjadi turun sehingga berefek pada bayi yaitu bayi menjadi lebih tenang dan tidak rewel (Roesli, 2011). Peredaran darah yang lancar akan membutuhkan oksigen (O2) lebih banyak dalam aliran darah dan akan terjadi peningkatan oksigen dalam sistem pernapasan. Menyemtuh kulit atau melakukan pijatan pelan akan menstimulasi peredarana darah dan akan meningkatkan energi lebih banyak oksigen (O2) yang akan ditranferkan ke otak sehingga akan memacu sistem peredaran darah dan pernapasan akan menjaddi lebih baik. Perasaan nyaman karena pijatan akan meningkatkan kualitas tidur (Field, et al., 2006; Gress, et al., 2010).

Pijat bayi bermanfaat untuk membantu relaksasi baik lokal ataupun umum. Area yang mendapatkan pijatan akan terjadi pelebaran pembuluh darah dan sikulasi darah akan meningkat (Dieter, et al., 2003; Guzzetta, et al., 2011). Kualitas tidur adalah susunan atau pola seseorang yang bebas dari gangguan atau bisa disebut kemampuan untuk tidur dengan pola teratur. Pola tidur teratur yaitu kebiasaan mudah tertidur, lama waktu tidur 20-30 menit mengalami tahap tidur secara teratur selama siklus tidur dari NREM sampai REM dengan waktu 90 menit setiap siklus tidur, jarang terbangun dan mudah kembali tertidur pada saat terbangun, merasa bugar pada saat bangun, memiliki konsentrasi yang tinggi pada aktivitas di siang hari. Menurut Ikatan Dokter Anak Indonesia (IKDAI) menyatakan bahwa waktu tidur yang kurang pada anak akan 
berdampak pada perkembangan fisik dan kognitif sebagai indikator perkembangan anak (Rini dan Nuri, 2006).

Bayi yang memiliki tidur efektif akan berdampak pada perkembangan otak di awal kehidupannya. Sinapsis otak akan berkembang, sinapsis adalah koneksi yang penting pada otak yang berperan dalam kemampuan belajar, bergerak, berfikir serta mengembangkan berbagai kreatifitas. Pada saat tidur maka tubuh akan memproduksi hormon pertumbuhan yang berperan dalam stimulasi pertumbuhan tulang dan jaringan, selain itu hormon pertumbuhan berperan dalam memperbaiki dan meregenerasi sel kulit, sel darah dan sel otak. Pada saat tidur pula kemampuan kognitif, mental, emosi dan konsentrasi dibentuk. Oleh sebab itu itur yang berkualitas sangat dibutuhkan oleh bayi (Praptiningsih, 2011).

\section{KESIMPULAN DAN SARAN}

Berdasarkan hasil penelitian diatas bisa disimpulkan bahwa bayi yang tidak melakukan pijat bayi mengalami kualitas tidur yang buruk di bandinkan dengan bayi yang melakukan pijat bayi. Pijat bayi yang dilakukan selama 3 kali dalam satu bulan mempengaruhi kualitas tidur bayi dibandingkan bayi yang hanya melakukan pijat bayi 2 kali dalam satu bulan.

Dari kesimpulan diatas maka peneliti memberikan saran kepada masyarakat terutama pada ibu yang mempunyai bayi untuk rutin melakukan pijat bayi karena pijat bayi terbukti bisa meningkatkan kualitas tidur bayi dengan baik. Bagi tenaga kesehatan diharapkan mampu memberikan penjelasan tentang manfaat pijat bayi dan cara melakukan pijat bayi yang benar. Bagi peneliti selanjutnya bisa menggunakan sampel yang lebih besar serta menambahkan variabel berupa pemeriksaan kadar hormon stress pada bayi yang melakukan pijat bayi.

\section{DAFTAR PUSTAKA}

Field, T, Diego, MA, Hernandez-Reif, M, Deeds, O \& Figuereido, B, (2006), Moderate versus light pressure massage therapy leads to greater weight gain in preterm infants, Infant
Behavior and Develepoment, 29(4), 574-578.

Danis, W dan Widyani, R. 2006. Panduan Perkembangan Anak 0-1 Tahun. Jakarta: Niaga Swadaya.

Dieter, JN, Field, T, Hernandez-Reif, M, Emory, EK \& Redzepi, M, (2003), Stable preterm infants gain more weight and sleep less after five days of massage therapy, Journal of Pediatric Psychology, 28(6), 403-411.

Gola, G. 2009. Ayo Bangun! Dengan Bugar Karena Tidur Yang Benar. Jakarta : Hikmah.

Gress, JL, Chambers, AS, Ong, JC, Tikotzy, L, Okada, RL \& Manber, R. 2010. Maernal subjective sleep quality and nighttime infant care, Journal of Reproductive and Infant Psychology, 28(4), 384-391.

Guzzetta, A, D'acunto, M, Carotenuto, M, Berardi, N, Bancale, A, Biagioni, E, Boldrini, A, Maffei, L, \& Cioni, G, (2011), The effects of preterm infant massage on brain electrical activity, Developemental Medicine \& Child Neurology, 53(4), 46-51.

Kusumastuti, N.A., Tamtomo, D dan Salimo, H. 2016. Effect of Massage on Sleep Quality and Motor Development in Infant Aged 3-6 Months. Journal of Maternal and Child Health. 1(3): 161169.

Wong, F.M dan Indraningsih. 2011. Smart Punktur Pijat untuk Mencerdaskan Otak. Tangerang: Penebar Plus.

Rini dan Nuri. 2006. Gangguan Tidur Pada anak Usia dibawah Tiga Tahun di Lima Kota di Indonesia. Jurnal Sari Pediatri. Vol. 7. No. 4. 
Roesli, U. 2007. Pedoman Pijat Bayi Prematur dan bayi usia 0-3 bulan. Jakarta. Trubus Agro Wijaya.

Roesli, 2011. Pedoman Pijat Bayi. Jakarta: Tribun Agriwidya.

Sofa, L., Yunani dan Hudhariani, R. 2013. Pengaruh Pijat Bayi Terhadap Kualitas Tidur Bayi Usia 3-6 Bulan Di Poliklinik Kesehatan Desa Purworejo Kecamatan Bonang Kabupaten Demak.
Sofwan, R. 2013. Bugar Selalu di Tempat Kerja. Jakarta : PT Bhuana Ilmu Populer.

Swarjana, I K. 2012. Metode Penelitian Kesehatan. Yogyakarta: CV Andi Offset.

Underdown, A., Barlow, J., Chung, V., dan Stewart-Brown, S. 2006. Massage intervention for promoting mental and physical health in infants aged under six months. Cochrane Database of Systematic Reviews, 18, CD005038. 